\title{
Cytogenetic biomonitoring of Brazilian dentists occupationally exposed to low doses of $\mathrm{X}$-radiation
}

\section{Monitorização citogenética de dentistas brasileiros ocupacionalmente expostos a baixos níveis de radiação $X$}

\author{
Cintia Kaori Miyaji* \\ Ilce Mara de Syllos Cólus**
}

\begin{abstract}
Exposure to X-rays (ionizing radiation) may cause chromosomal aberrations (CA) in somatic or germinative cells in exposed individuals, and may lead to manifestations of diseases such as cancer. This study was carried out to assess the CA frequency in lymphocytes obtained by means of temporary culture of peripheral blood from dentists in Londrina, Paraná, Brazil, who have worked for more than ten years with X-rays. The results obtained from the experimental group were compared with a matched negative control group, which had never been exposed to X-rays. All individuals, dentists and controls, answered a personal questionnaire, from which a profile of each group was obtained. Slides, prepared after the cultures, were stained with Giemsa, and 100 to 200 metaphase cells were analyzed per individual. CA frequencies and types were registered and statistical tests were not necessary to evaluate the obtained data. The analysis of mitotic index (MI) did not indicate significant differences $(\mathrm{p}<0.05)$ between the group of individuals exposed to X-rays and the control group. The analyzed confounding factors did not influence the results of MI and CA frequencies.
\end{abstract}

UNITERMS: Chromosome aberrations; Occupational exposure; Mitotic index; Dentist's practice patterns; X-rays.

RESUMO: A exposição à radiação ionizante pode causar aberrações cromossômicas (AC) em células somáticas ou germinativas dos indivíduos expostos, podendo levar a manifestações de doenças como os cânceres. Este trabalho teve como objetivo avaliar a freqüência de $\mathrm{AC}$ em linfócitos obtidos através de cultura temporária do sangue periférico de dentistas de Londrina (Paraná - Brasil), com mais de dez anos de trabalho com raios X. Os resultados obtidos do grupo experimental foram comparados com um grupo controle negativo pareado, que nunca se expôs ocupacionalmente aos raios X. Todos os indivíduos, dentistas e controles, responderam a um questionário pessoal, a partir do qual foi obtido um perfil de cada grupo. Após as culturas, as lâminas foram confeccionadas, coradas com solução de Giemsa e foram analisadas de 100 a 200 células metafásicas por indivíduo, anotando-se as freqüências e tipos de AC encontrados. Não foi necessária a realização de testes estatísticos para avaliação desses parâmetros. A análise dos índices mitóticos (IM) não indicou diferenças significantes $(\mathrm{p}<0,05)$ entre os individuos dos grupos expostos e controle. Os fatores de variação analisados não influenciaram os resultados obtidos para o IM e freqüência de AC.

UNITERMOS: Aberrações cromossômicas; Exposição ocupacional; Índice mitótico; Condutas na prática dos dentistas; Raios X.

\section{INTRODUCTION}

Ionizing radiation may be classified as direct or indirect. X-rays are indirectly ionizing. They do not produce chemical or biological damage themselves, but when they are absorbed by the material through which they pass, they give up their energy to produce fast-moving charged particles ${ }^{10}$. The atoms of critical targets in the cells, such as DNA, RNA and proteins, may be ionized or excited, thus initiating a chain of events that leads to biological change.

Exposure to different sources of X-ray varies substantially in both radiation quality and dose.
The exposure may be acute or partial, and possibly confounded by the health of the exposed person ${ }^{16}$.

Among the biological effects of ionizing radiation, chromosomal aberrations must be pointed out $^{10}$. They have become well established, during the last two or three decades, as a means of measuring the exposure to ionizing radiation ${ }^{9}$. An additional evaluation of the potential of physical and chemical agents in producing effects on cells can be carried out by analyzing the proportion of mitotic cells and calculating a mitotic index. Depression of the mitotic index is usually a consequence of a reduced rate of cell proliferation (mitotic delay) $)^{8,25}$.

*Master in Genetics and Enhancement; **Associate Professor - Department of General Biology, State University of Londrina. 
Miyaji CK, Cólus IM de S. Cytogenetic biomonitoring of Brazilian dentists occupationally exposed to low doses of X-radiation. Pesqui Odontol Bras 2002;16(3):196-201.

A cell type commonly used to monitor populations occupationally exposed to radiation is the lymphocyte from human peripheral blood. When there are chronic exposures to X-rays, the chromosomal aberrations induced in lymphocytes at the G0 phase of the cell cycle accumulate in the longlife lymphocyte population. The frequency of chromosomal aberration, especially dicentric chromosomes, can be considered as a sensitive indicator of the exposure to ionizing radiation ${ }^{7}$ (Bender et al., 1988 apud Weber et al. $\left.{ }^{27}, 1995\right)$.

There are few studies that assess the genetic effects of human in vivo exposure to radiation using lymphocytes from the peripheral blood. The available data include studies carried out on individuals occupationally exposed to high doses ${ }^{11,3}$; patients ${ }^{27}$; people who were accidentally exposed ${ }^{20,18,6,23}$ and persons occupationally exposed to low doses of ionizing radiation ${ }^{9,13,28}$.

In Brazil, a large group of dentists who are not specialists in radiology deal in their offices with low doses of ionizing radiation without utilizing dosimeters. This fact led us to select these professionals for a cytogenetic biomonitoring of exposure to X-rays, using as parameters the analysis of the frequencies of chromosome aberration and mitotic indexes in lymphocytes from the peripheral blood of 28 dentists from Londrina, Paraná, Brazil, who had been exposed for at least ten years to low X-radiation levels.

\section{MATERIALS AND METHODS}

The exposed group was composed of 28 dentists (14 women and 14 men) from Londrina, Paraná, Brazil, who had been occupationally exposed to X-rays for 21 years on average (Table 1). Twenty-three out of the twenty-eight studied individuals were Caucasians, while the others belonged to different ethnic groups.

Standardized questionnaire forms were used to collect information from all subjects who agreed to participate in this study. According to the procedures of Carrano, Natarajan ${ }^{4}$ (1988), the questions assessed age, marital status, working environment, dosimeter use, smoking and alcohol habits and history of recent illnesses and medical treatments. Each dentist was matched by age, sex and smoking habits with an unexposed individual who lived in the same city and worked in administrative offices. The control group was composed of healthy individuals: 11 women and 13 men from Londrina, who had never been occupationally exposed to ra- diation. The utilization of appropriate controls is essential in this type of study. According to Kasuba et al. ${ }^{12}$ (1995), the evaluation of structural $\mathrm{CA}$ of the general population is necessary for the interpretation and recognition of the pattern of responses in a population who is occupationally exposed to physical and chemical mutagens.

Non of the individuals (dentists and controls) had received chemotherapeutic or cytostatic drugs in the 12 months previous to blood collection.

Venous heparinized blood samples were drawn concurrently from each dentist and the matched control donor and processed at the Cytogenetic and Mutagenesis Laboratory of the State University of Londrina. Blood cultures were set up as follows: heparinized plasma was cultivated at $37^{\circ} \mathrm{C}$ for $52 \mathrm{~h}$ in $80 \%$ of RPMI 1,640 medium (Sigma) supplemented with $20 \%$ fetal calf serum (Cultilab), $2 \%$ of phytohemaglutinin (Gibco) and $0.01 \%$ antibiotic/antimicotic solution (Sigma). Metaphases were obtained by adding $8 \mathrm{mg} / \mathrm{ml}$ medium colchicine solution (Sigma) to the cultures $1.5 \mathrm{~h}$ before harvesting. After hypotonic shock $(\mathrm{KCl}$ $0.075 \mathrm{M}$ ) for 20 minutes at $37^{\circ} \mathrm{C}$ and fixation in methanol acetic acid $(3: 1, v / v)$, chromosome preparations were stained with 3.3\% Giemsa (Merck) diluted in phosphate buffer, $\mathrm{KH}_{2} \mathrm{PO}_{4} 0.06 \mathrm{M}$ and $\mathrm{Na}_{2} \mathrm{HPO}_{4} 0.06 \mathrm{M}(\mathrm{pH}=6.8)$ for 5 minutes.

The coded slides were scored and analyzed at a magnification of $1,000 \mathrm{X}$. A total of 100 to 200 cells/individual were screened in the control group and in the exposed group, and different types of aberrations were classified. The mitotic indexes were calculated $(\mathrm{IM}=$ number of cells in division/number of analyzed cells) for both groups. Comparative analysis of mitotic indexes was obtained using a one-way ANOVA test.

\section{RESULTS}

An average of 188 and 177 metaphases per individual were analyzed, and relative frequencies of 0.25 and 0.02 of chromosomal aberrations were found in the control and exposed group, respectively (Table 1). There were no detectable differences between the frequencies of CA or cells with $\mathrm{CA}$ in the lymphocytes of dentists and those of controls. Since the frequency of chromosomal aberrations was low, statistical tests were not necessary to evaluate this aspect.

The mitotic indexes were analyzed by means of a one-way ANOVA test, but no statistically significant differences were found between the control 
Miyaji CK, Cólus IM de S. Cytogenetic biomonitoring of Brazilian dentists occupationally exposed to low doses of X-radiation. Pesqui Odontol Bras 2002;16(3):196-201.

TABLE 1 - Characterization of the samples (control and $\mathrm{X}$-ray-exposed populations), frequencies of chromosomal aberrations (CA) and mitotic index.

\begin{tabular}{|c|c|c|c|}
\hline \multirow{2}{*}{\multicolumn{2}{|c|}{ Sample characteristics }} & \multicolumn{2}{|c|}{ Populations } \\
\hline & & Control & Exposed \\
\hline \multicolumn{2}{|c|}{ Number of individuals } & 24 & 28 \\
\hline \multicolumn{2}{|c|}{ Exposure time (years) $(\overline{\mathrm{X}} \pm \mathrm{SE})$} & 0 & $21.39 \pm 8.20$ \\
\hline \multirow{2}{*}{ Sex } & Female & 11 & 14 \\
\hline & Male & 13 & 14 \\
\hline \multicolumn{2}{|c|}{ Age (years) $(\overline{\mathrm{X}} \pm \mathrm{SE})$} & $43.58 \pm 8.17$ & $44.14 \pm 9.33$ \\
\hline \multirow{3}{*}{ Smoking habits } & Smokers & 6 & 6 \\
\hline & Non smokers & 6 & 7 \\
\hline & Ex-smokers & 12 & 15 \\
\hline \multirow{3}{*}{$\begin{array}{l}\text { Chromosome } \\
\text { aberrations }\end{array}$} & $\begin{array}{l}\text { Number of } \\
\text { analyzed cells } \\
(\overline{\mathrm{X}} \pm \mathrm{SE})\end{array}$ & $188.6 \pm 27.5$ & $177.4 \pm 34.9$ \\
\hline & $\begin{array}{l}\text { Total of CA } \\
(\bar{X} \pm \mathrm{SE})\end{array}$ & $0.46 \pm 0.17$ & $0.04 \pm 0.08$ \\
\hline & $\begin{array}{l}\text { Number of } \\
\text { CA/100 } \\
\text { analyzed cells }\end{array}$ & 0.25 & 0.02 \\
\hline \multicolumn{2}{|c|}{$\begin{array}{l}\text { Mitotic index }(1,000 \text { cells/indi- } \\
\text { vidual })(X \pm S E)\end{array}$} & $3.14 \pm 0.24$ & $2.71 \pm 0.20$ \\
\hline
\end{tabular}

$\overline{\mathrm{X}} \pm \mathrm{SE}=$ mean \pm standard error.

and exposed groups $(\mathrm{F}=1.58 ; \mathrm{p} \leq 0.05)$. Hence, X-rays did not have a cytotoxic effect on dentists' lymphocytes. The analyzed confounding factors age, sex, smoking habit and period of occupational exposure to X-rays (21.39 \pm 8.20 years) - did not show any influence on the results of neither the mitotic index nor the frequency of chromosomal aberrations in this study.

\section{DISCUSSION}

According to Upton $^{26}$ (1982), the effects of exposure to low radiation doses accumulate in the body and may damage health after several years of exposure.

The data on human in vivo exposure to radioactive materials are generally obtained after acute accidental exposures ${ }^{19}$; the most famous cases were the A-bomb in Hiroshima and Nagasaki1, the Chernobyl nuclear plant ${ }^{6,14}$ and the accident with Cesium $^{137}$ in Goiânia ${ }^{21}$, where people were exposed to high and acute doses of radioactive material.
This type of exposure can cause hair loss, skin burns or even the death of some individuals exposed to very high doses. Cruz et al. ${ }^{5}$ (1997) detected the development of tumors in seven exposed individuals, ten years after the radioactive accident in Goiânia. However, it is difficult to attribute a specific cancer to ionizing radiation.

There are evidences of association between occupational exposure, cytogenetic alterations and the increase in cancer rates ${ }^{15}$. It is known that the probability of carcinogenesis is greater in populations exposed to radiation, since ionizing radiation can raise the frequency of $\mathrm{CA}$ and spontaneous mutations. According to Preston ${ }^{17}$ (1997), all tumors contain chromosome alterations; specific deletions and translocations are involved in different stages of the development of the tumor, and unspecific alterations are common in genomic instability, which is a characteristic of tumors.

Assessments of the cytogenetic impact of chronic exposure to low radiation doses are scarce. Dentists are workers occupationally exposed to low levels of ionizing radiation, and there is no regular effective inspection of their work environment - the prevention of exposure to X-rays generally depends only on the common sense of the professional. Although this chronic form of exposure is the most common, there are no reports on cytogenetic monitoring of this group of professionals. Therefore, in this study, the frequencies of CA and MI were assessed in dentists who had at least ten years of exposure to X-rays, since the mean lifetime of long-lived lymphocytes is seven years.

Stable (balanced translocations, paracentric inversions) and unstable (dicentric and acentric fragments and rings) chromosomal aberration types are normally found after exposure to X-rays. The latter are generally observed as a consequence of exposure to acute ionizing radiation in vitro or in vivo ${ }^{9}$. Unstable chromosomal aberrations were not detected in the present study, which corroborates the previous statement. Stable aberrations are detected only by applying specific techniques of chromosome staining and were not detected in the present study since we carried out a conventional cytogenetic analysis. However, the possibility of there being stable type aberration in this sample cannot be discarded.

Studying the effects of radiation on survivors of the Hiroshima and Nagasaki A-bombs, Awa ${ }^{1}$ (1990) observed a significant increase in the frequency of dicentric chromosomes and rings when 
Miyaji CK, Cólus IM de S. Cytogenetic biomonitoring of Brazilian dentists occupationally exposed to low doses of X-radiation. Pesqui Odontol Bras 2002;16(3):196-201.

the number of cells analyzed was increased to 500 per individual. In our study, the average of analyzed cells from the exposed group was 177 (Table 1); perhaps an increase in the number of analyzed cells would lead to different results. However, it was not possible to analyze a greater number of cells in the present work.

Cytogenetic monitoring of hospital workers exposed to low doses of ionizing radiation has been carried out by means of analyzing the frequencies of chromosomal aberration ${ }^{9}$ or centromere-positive micronuclei ${ }^{24}$, comparing the results with those of a control group. A biologically significant result was obtained. Jha, Sharma ${ }^{11}$ (1991) found a greater frequency of acentric chromosomes in workers occupationally exposed to radiation for radiological diagnoses, when compared with control individuals.

The present study, however, did not corroborate these findings because there were no detectable differences between the frequencies of CA or cells with CA in lymphocytes of 28 dentists of Londrina, Paraná, Brazil, who were occupationally exposed to low levels of radiation, and the frequencies of $\mathrm{CA}$ or cells with CA in the control group, in paired data analysis. We registered $0.25 \mathrm{CA} / 100$ analyzed cells from the control individuals and $0.02 \mathrm{CA} / 100$ metaphases analyzed in cells from exposed individuals (Table 1). Although a greater frequency of chromosome aberration was observed in the control group, the frequency is still within the level considered normal by Kasuba et al. ${ }^{12}$ (1995) for blood lymphocytes from control individuals: from 0 to $6.7 \mathrm{CA} / 100$ cells.

According to the questionnaires answered in the present study, on average, each dentist utilizes the X-ray device 4.8 times a day, without using dosimeters during their activities. Thus, we have no precise information on the exact dose to which the subjects had been exposed. When dentists were asked about the adoption of safety measures while handling X-rays devices, 96.42\% replied affirmatively. This fact may have contributed to the low frequency of chromosomal aberration found in this sample.

Several authors, such as Biggati et al. ${ }^{2}$ (1988), observed that workers with 5 to 20 years of professional exposure do not have increased frequencies of chromosomal aberration related to working period. Similarly, in the present study, workers had been exposed for $21.39 \pm 8.20$ years to X-rays and a correlation between this parameter and CA was not observed.

Correlating clastogenicity and cytotoxicity of a given agent is a very complex study, since there are several parameters to assess cytotoxicity. MI is normally measured and it can detect the increase or decrease in cell proliferation rate ${ }^{8}$. In the present study, the mitotic index of the control group was not statistically different from that of the exposed group, indicating that there were no cytotoxic effects from ionizing radiation on the lymphocytes from the studied dentists. We also did not observe a correlation between the working period of dentists with X-rays $(21.39 \pm 8.20$ years $)$ and MI frequencies.

In spite of the fact that confounding factors age, sex and smoking habits - potentially play a role in the induction or expression of CA and MI, in the present study, no associations between these parameters and the occurrence of CA or MI were found.

It is important to point out that high frequencies of chromosomal aberration in individuals occupationally exposed to genotoxic and/or carcinogenic agents may be considered a relevant biological marker to demonstrate a future cancer case $^{22}$. Thus, the increase in the number of studies in this area is necessary and important, since the present study presents negative results.

Therefore, this type of study may become an indicator of the need for greater control and protection against the harmful effects of radiation over occupationally exposed professionals. The results of the present study revealed that in this group of professionals, whose work environments were not regularly inspected, dentists exposed to 10 years or more of ionizing radiation presented CA and MI levels similar to those of control individuals, which indicates the adoption of safety measures during occupational exposure.

\section{CONCLUSIONS}

The data presented here indicate that the frequencies of CA and the MI of dentists professionally exposed to low doses of ionizing radiation were similar to those of the matched control individuals. There were no associations between the confounding factors age, sex and smoking habits and the frequency of CA and on MI. However, the absence of chromosomal aberrations does not exclude other possible damages to DNA. 
Miyaji CK, Cólus IM de S. Cytogenetic biomonitoring of Brazilian dentists occupationally exposed to low doses of X-radiation. Pesqui Odontol Bras 2002;16(3):196-201.

The negative results of our study suggest that Brazilian dentists chronically exposed to X-rays take sufficient precautions during the exposure in their work environment or that the level of exposure was not enough to produce damage. Therefore, other studies involving an increased number of individuals are necessary in order to obtain more reliable conclusions about the cytogenetic impact of the chronic exposure of dentists to low levels of ionizing radiation.

\section{REFERENCES}

1. Awa AA. Chromosome aberrations. In: A-bomb survivors, Hiroshima and Nagasaki. In: Chromosomal aberrations - basic and applied aspects. Berlim: Springer-Verlag; 1990. p. 180-90.

2. Biggati P, Lamerti L, Arditto G, Armellino F. Cytogenetic monitoring of hospital workers exposed to low-level ionizing radiation. Mutat Res 1988;(204):343-7.

3. Braselmann H, Schmid E, Bauchinger M. Chromosome aberrations in nuclear power plant workers: the influence of dose accumulation and lymphocyte life-time. Mutat Res 1994;(306):197-202.

4. Carrano A, Natarajan AT. International Comission for Protection against Environmental Mutagens and Carcinogens. ICPEMC Publication n. 14. Consideration for population monitoring using cytogenetic techniques. Mutat Res 1988;(204);379-406.

5. Cruz AD, Volpe JP, Saddi V, Curry J, Curado MP, Glickman BW. Radiation risk estimate in human population: lesson from the radiological accident in Brazil. Mutat Res 1997;(373):207-14.

6. Emerit I, Quastel M, Goldsmith J, Merkin J, Levy A, Cernjavski L, Alaoui-Youssefi A, Pogossian A, Riklis E. Clastogenic factors in the plasma of children exposed at Chernobyl. Mutat Res 1997;(373):47-53.

7. Evans HJ, Buckton KE, Hamilto GE, Carothers A. Radiation-induced chromosome aberrations in nuclear-dockyard worker. Nature 1979;(277):531-4.

8. Galloway SM, Aardema MJ, Ishidate Jr M, Ivett JL, Kirkland DJ, Morita T, Mosesso P, Sofuni T. Report from working group in vitro tests for chromosomal aberrations. Mutat Res 1994;(312):241-61.

9. Hagelström AH, Gorla NB, Larripa IB. Chromosomal damage in workers occupationally exposed to chronic low level ionizing radiation. Toxicol Lett 1995;(76):113-7.

10. Hall EJ. The physics and chemistry of radiation absorption. In: Radiobiology for the radiologist. 4rd ed. Philadelphia: Lippincott; 1994. p. 1-13.

11. Jha NA, Sharma T. Enhanced frequency of chromosome aberrations in workers occupationally exposed to diagnostic X-rays. Mutat Res 1991;(260):343-8.

12. Kasuba V, Sentija K, Garaj-Vrhovac V, Fucic A. Chromosome aberrations in peripheral blood lymphocytes from control individuals. Mutat Res 1995;(346):187-93.

13. Kruszewski M, Wojewódzka M, Iwanenko T, Collins AR, Szumiel I. Applications of the comet assay for monitoring DNA damage in workers exposed to chronic

\section{ACKNOWLEDGMENTS}

We thank the North Paraná Dental Association and the studied volunteers. We would like to thank Miss Angela Mehta for the English revision and Mr. Dario P. Tormena; Mr. José Cláudio Cristiano; Mr. José Severino and Mr. Ricardo A. da Silva for technical assistance.

low-dose irradiation II. Base Damage. Mutat Res 1998;(416):37-57.

14. Lazutka JR, Lekevicius R, Dedonyte V, MaciuleviciuteGrrvers L, Mierauskien J, Rudaintien S, Slapsyte G. Chromosomal aberrations and sister-chromatid exchanges in Lithuan populations: effects of occupational and environmental exposures. Mutat Res 1999;(445): 225-39.

15. Mitelman F. Catalog of chromosome aberrations in cancer. 5th ed. New York: Wiley; 1994.

16. Otake M, Schull WJ, Neel JV. Congenital malformations, stillbirths, and early mortality among the children of atomic bomb survivors; a reanalysis. Radiat Res 1990;(122):1-11.

17. Preston RJ. Short/medium term carcinogenicity tests and genetic and related effects. IARC Meeting - Lyon; 1997.

18. Ramalho AT, Curado MP, Natarajan AT. Results of a cytogenetic follow-up study 7,5 years after $\mathrm{Cs}^{137}$ exposure at the Goiânia (Brazil) radiological accident. Radiat Protect Dosim 1996;(64):319-21.

19. Sasaki MS, Ejima Y, Saigusa S. Biological dosimetry of absorbed radiation dose: considerations of low-level radiation. In: Chromosomal aberrations. Basic and applied aspects. Berlin: Springer-Verlag; 1990. p. 191-201.

20. Schull WL, Otake M, Neal JV. Genetic effects of the atomic bomb: a reapprasial. Science 1981;(213):1220-7.

21. Skandalis A, Cruz AD, Curry J, Nohturfft A, Curado MP, Glickman BW. Molecular analysis of T-lymphocyte HPRT mutations in individuals exposed to ionizing radiation in Goiania, Brazil. Environ Mol Mutagen 1997;(29):107-16.

22. Sorsa M, Ojajarvi A, Salomaa S. Cytogenetic surveillance of workers exposed to genotoxic chemicals: preliminary from a prospective cancer study in a cytogenetic cohort. Teratog Carcinog Mutagen 1990;(10):215-21.

23. Stephan G, Pressl S. Chromosome aberrations in human lymphocytes analysed by fluorescence in situ hibridization after in vitro irradiation, and in radiation workers, 11 years after an accidental radiation exposure. Int $\mathrm{J}$ Radiat Biol 1997;71(3):293-9.

24. Thierens H, Vral A, Morthier R, Aousalah B, De Riidder LD. Cytogenetic monitoring of hospital workers occupationally exposed to ionizing radiation using the micronucleus centromere assay. Mutagenesis 2000;15(3): 245-9. 
Miyaji CK, Cólus IM de S. Cytogenetic biomonitoring of Brazilian dentists occupationally exposed to low doses of X-radiation. Pesqui Odontol Bras 2002;16(3):196-201.

25. United Kingdom Environmental Mutagen Society. Report of UKEMS Sub-Committee on Guidelines for Mutagenicity Testing. Ed. by B. J. Dean, UKEMS 1983; p. 48.

26. Upton AC. The biological effects of radiation. Scient Americ 1982;(246):41.

27. Weber J, Scheid W, Traut H. Biological dosimetry after extensive diagnostic X-ray exposure. Healthy Physics 1995;68(2):266-9.
28. Wojewódzka M, Kruszewski M, Iwanenko T, Collins AR, Szumiel I. Applications of the comet assay for monitoring DNA damage in workers exposed to chronic low-dose irradiation I. Strand breakage. Mutat Res 1998;(416):21-35.

Recebido para publicação em 12/11/01 Enviado para reformulação em 10/04/02 Aceito para publicação em 14/05/02

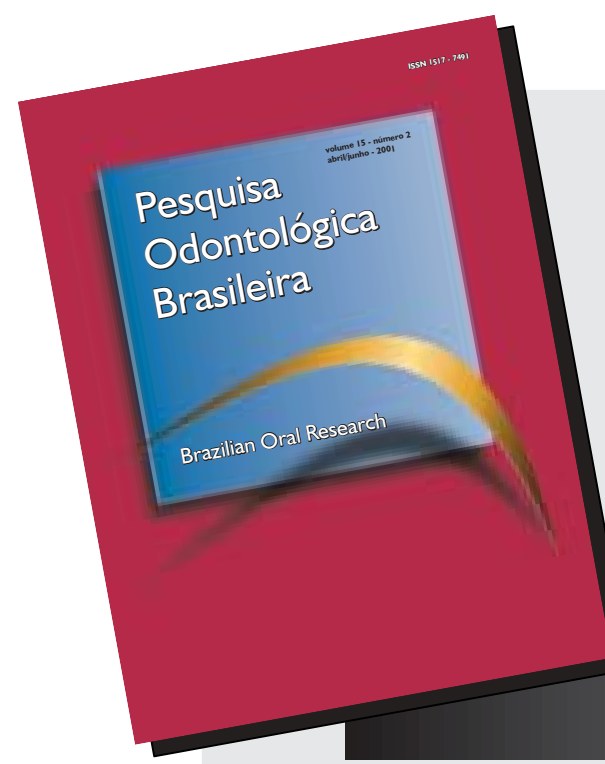

$M$ antenha-se informado sobre os mais recentes desenvolvimentos da pesquisa odontológica no país. Invista em seu aprimoramento científico e tecnológico.

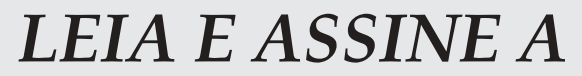

\section{Pesquisa Odontológica Brasileirra}

Valor da assinatura:

Publicação oficial da Sociedade

sócio da SBPqO: R\$ 50,00

não sócio da SBPqO: $R$ \$ 150,00

Brasileira de Pesquisa Odontológica

institucional: $\mathbf{R} \$ 200,00$

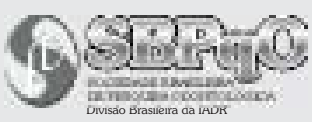

Envie carta contendo dados pessoais, endereço completo e cheque nominal à "SBPqO / $\mathrm{POB}$ ", solicitando sua assinatura.

Endereço: SBPqO - Sociedade Brasileira de Pesquisa Odontológica Av. Professor Lineu Prestes, 2227 - CEP 05508-900 - Cidade Universitária São Paulo - SP - Tel./fax: (0xx11) 3091-7855 - e-mail: sbpqo@sbpqo.org.br 